University of Nebraska - Lincoln

DigitalCommons@University of Nebraska - Lincoln

Faculty Publications: Agricultural Leadership, Education \& Communication Department
Agricultural Leadership, Education \& Communication Department

December 2005

\title{
Motivation and Transactional, Charismatic, and Transformational Leadership: A Test of Antecedents
}

John E. Barbuto Jr.

University of Nebraska - Lincoln, jbarbuto@unInotes.unl.edu

Follow this and additional works at: https://digitalcommons.unl.edu/aglecfacpub

Part of the Other Public Affairs, Public Policy and Public Administration Commons

Barbuto, John E. Jr., "Motivation and Transactional, Charismatic, and Transformational Leadership: A Test of Antecedents" (2005). Faculty Publications: Agricultural Leadership, Education \& Communication Department. 39.

https://digitalcommons.unl.edu/aglecfacpub/39

This Article is brought to you for free and open access by the Agricultural Leadership, Education \& Communication Department at DigitalCommons@University of Nebraska - Lincoln. It has been accepted for inclusion in Faculty Publications: Agricultural Leadership, Education \& Communication Department by an authorized administrator of DigitalCommons@University of Nebraska - Lincoln. 


\title{
Motivation and Transactional, Charismatic, and Transformational Leadership: A Test of Antecedents
}

\author{
John E Barbuto Jr
}

\begin{abstract}
Relationships between leaders' motivation and their use of charismatic, transactional, and / or transformational leadership were examined in this study. One hundred eighty-six leaders and 759 direct reports from a variety of organizations were sampled. Leaders were administered the Motivation Sources Inventory (MSI) while followers reported leaders' full range leadership behaviors using the Multifactor Leadership Questionnaire (MLQ-rater version). Leaders were also administered the self-rating version of the Multi-factor Leadership Questionnaire (MLQ-rater version). The Motivation Sources Inventory subscales subsequently significantly correlated with leader self-reports of inspirational motivation, idealized influence (behavior) and individualized consideration (range, $r=.10$ to .29), as well as with raters' perceptions of inspirational motivation, idealized influence (behavior) and individualized consideration (range, $r=.18$ to .19). The Motivation Sources Inventory subscales significantly correlated with leaders' self-reports of charisma, transactional and laissez-faire leadership (range, $r=.12$ to $.28)$, with rater-reports of the same variables (range, $r=.16$ to .29 ).
\end{abstract}

Antecedents of transformational behavior have been examined sparsely since the concept was first articulated and researched (Burns, 1978; Bass, 1985). Those few studies that have examined the construct as a criterion variable have included Avolio's (1994) examination of life events and experiences, Bass's (1985) exploration of early career challenges, Howard and Bray's (1988) study of personality variables, Atwater and Yammarino's (1993) study of personal attributes as precedents to transformational leader behaviors, and Barbuto,
Fritz, and Marx's (2000) study of work motivation and transformational leadership. Results of these inquiries demonstrate that dispositional variables play some role in transformational leadership, but much research is necessary to ascertain which variables explain the greatest variance in data. This study tests the relationship between leaders' sources of motivation and their use of transactional, charismatic, and transformational leadership.

\section{Literature Review}

\section{Full Range Model of Leadership}

Transformational leadership theories grew from Burns's (1978) work in political leadership. Burns (1978) described the transforming leader as one who is able to lift followers up from their petty preoccupations and rally around a common purpose to achieve things never thought possible. Bass (1985) developed a typology of leadership behaviors fitting into the broad categories of transactional and transformational leadership. Bass (1985) identified laissez-faire, management-byexception, and contingent reward as the key types of transactional leadership. Most conceptualizations of transactional leadership, however, exclude laissez-faire because it represents the absence of leadership.

Transformational leadership was operationalized at the time to include charisma, intellectual stimulation, and individualized consideration (see Avolio, Waldman \& Einstein, 1988; Bass, 1990). Through theory refinements and research, a fourth component of transformational leadership was identified inspirational motivation. Later, after one of the key components - charisma - received increased scrutiny and criticism as potentially 
incompatible with transformational ideals (see Barbuto, 1997; Hunt, 1999), the term 'charisma' in the full range leadership model was eventually changed to idealized influence. The full range leadership model describes the distribution of leadership behaviors, ranging from completely inactive (laissez-faire) to transactional behaviors to transformational behaviors.

\section{Transactional Leadership}

Bradford and Lippitt (1945) described laissez-faire leadership as a leader's disregard of supervisory duties and lack of guidance to subordinates. Laissez-faire leaders offer little support to their subordinates and are inattentive to productivity or the necessary completion of duties. Lewin, Lippitt and White (1939) studied boys' clubs in which adults were taught to lead each group as either a laissez-faire leader or a democratic leader. Laissez-faire leaders gave their groups complete freedom and offered little guidance. These groups proved to be confused and disorganized, and their work was less efficient and of poorer quality than the work of groups whose leaders exhibited different behaviors. From the outset, laissez-faire has demonstrated itself to be the most inactive, least effective, and most frustrating leadership style. Katz, Macoby, Gurin, and Floor (1951) studied railroad section groups that were deemed to be unproductive. The leaders of these groups gave complete control to the group members and the members did not respond to the challenge. Studies show that policies and practices that reflect non-involvement of supervisors lead to low productivity, resistance to change, and low quality of work (Argyris, 1954; Berrien, 1961; Murnigham \& Leung, 1976).

Management-by-exception has it roots in contingent reinforcement theories (Bass, 1990) whereby subordinates are rewarded or punished for a designated action. Leaders practicing management-by-exception do not get involved with subordinates until failures or deviations in workflow occur (Bass, 1985; 1990). Intervention by the leader occurs only when a failure takes place and punishment or corrective action is necessary. The leader sets up predetermined actions for specific failures and enforces the punishments when necessary. Passive leaders tend to get involved only when necessary and refuse to set a plan of action. Such leaders expect only the status quo from subordinates, do not encourage exceptional work (Hater \& Bass, 1988), and wait to be notified of failures. Active leaders, unlike their passive counterparts, regularly search for failures and devise systems that warn of impending failures before they occur (Hater \& Bass, 1988).

Leaders who practice management by exception routinely provide negative feedback because they only initiate contact with subordinates when failures occur. This action stimulates subordinates to maintain the status quo and strive for perfection at their job. However, the behavior does not encourage or foster growth of the person or job performance. In a management-by-exception environment, any non-routine circumstances will require leader intervention, because employees have not been encouraged to solve problems and have not been given the autonomy to develop confidence or to learn from experiences (See Bass, 1985; 1990).

Leaders and followers both participate in a contingent rewards approach to management, because it reflects behavior that is reciprocal in nature (Howell \& Avolio, 1993). Each party agrees to a system of rewards and works to meet mutual expectations for certain achievements or behaviors (Bass, 1990; Seltzer \& Bass, 1990). This approach stems partly from reinforcement theory and has been central to leadership theory and practice for many years. Bass (1990) described many examples from early Greek mythology in which contingent rewards were used by the gods. Kelman (1958) discussed instrumental compliance and instrumental inducements in early discussions of this type of leadership. Blanchard and Johnson (1985) described transactional management as a simple process of creating strong expectations with employees, along with clear indications of what they will get in return for meeting these expectations. Most research has linked contingent rewards to positive organizational outcomes (Howell \& Avolio, 1993; Lowe, Kroeck, \& Sivasubramaniam, 1996). 


\section{Charismatic Leadership}

Charisma is believed to be the fundamental factor in the transformational process and is described as the leader's ability to generate great symbolic power. Weber (1947) first described the concept of charismatic leadership as stemming from subordinates' (or followers') perceptions that the leader is endowed with exceptional skills or talents. In its origins, charismatic leadership was a focus in studying political and world leaders (Burns, 1978; House, Spangler \& Woycke, 1991). Research of charismatic leadership has consistently found significant relationships with follower trust, effort, and commitment (Howell \& Frost, 1989; Lowe et al., 1996).

\section{Transformational Leadership}

Bass (1985) espoused a theory of transformational leadership that built on the earlier works of Burns (1978). The degree to which leaders are transformational was measured in terms of the leader's effect on followers. Followers of transformational leaders feel trust, admiration, loyalty, and respect toward leaders and are motivated to perform extra-role behaviors (Bass, 1985; Katz \& Kahn, 1978). Transformational leaders have been shown to increase followers' trust satisfaction and citizenship (Podsakoff, MacKenzie, Morrman \& Fetter, 1990). Leaders high in transformational behaviors achieve maximum performance from followers because they are able to inspire followers to raise their criteria for success and develop innovative problem solving skills (Bass, 1985; Yammarino \& Bass, 1990).

The transformational leader-follower relationship is viewed as one of mutual stimulation and is operationalized with three distinct characteristics: intellectual stimulation, individualized consideration, and inspirational motivation (Barbuto, 1997; Bass, 1985; Bass \& Avolio, 1990). Individualized consideration describes leaders acting in the role of employee mentors (Bass, 1985). Inspirational motivation describes leaders passionately communicating a future idealistic organization that can be shared (Hater \& Bass, 1988). Intellectual stimulation describes leaders encouraging employees to approach old and familiar problems in new ways (Bass, 1985; Deluga, 1988).
The motives inherent in the full-range leadership model have been examined surprisingly little during the past 20 years of transformational leadership research. This project, therefore, tests the specific relationships between leaders' sources of work motivation and the full range leadership behaviors used by leaders in the workplace. The next section reviews the motivation literature and develops the expected relationships between the variables of interest.

\section{Sources of Motivation in the Workplace}

\section{Toward a Meta-Theory of Work Motivation}

Leonard, Beauvais, and Scholl (1999) proposed a new typology of motivation sources, which was later operationalized with scales to measure the taxonomy (Barbuto \& Scholl, 1998). This taxonomy was further developed and tested to predict leaders' behaviors (Barbuto \& Scholl, 1999; Barbuto, Fritz \& Marx, 2000). In two independent research studies examining antecedents of leaders' behaviors (using these two motivation taxonomies), the five sources of motivation (Barbuto \& Scholl, 1998; Leonard, Beauvais \& Scholl, 1999) were better able to predict behavior than McClelland's (1985) three-need model (see Barbuto, Fritz \& Marx, 2000; 2002). These five sources of motivation include intrinsic process, instrumental, selfconcept-external, self-concept-internal, and goal internalization.

\section{The Five Sources of Work Motivation}

\section{Intrinsic Process Motivation}

If people are motivated to perform certain kinds of work or to engage in certain types of behavior for the sheer fun of it, then intrinsic process motivation is occurring. For this source of motivation, the work itself acts as the incentive because workers enjoy what they are doing. Similar constructs to intrinsic process motivation can be found extensively in the literature. Developmental theorists have described a similar motive using the terms heteronymous morality (Kohlberg, 1976), 
impulsive (Loevinger, 1976; Kegan, 1982), and, to a lesser extent, pre-operational (Piaget, 1972). Other need-based descriptors similar to intrinsic process include early existence needs (Alderfer, 1969), intrinsic pleasure needs (Murray, 1964) and physiological needs (Maslow, 1954). Bandura (1986) describes sensory intrinsic motivation and physiological intrinsic motivation in terms similar to those used to describe intrinsic process motivation. This motive also has been articulated as intrinsic motivation to obtain task pleasure (Deci, 1975) and intrinsic task motivation devoid of external controls or rewards (Staw, 1976).

Past researchers (Deci, 1975; Katz \& Kahn, 1978; Staw, 1976) have used the term intrinsic motivation to represent personal satisfaction derived from achievement of goals or tasks. Intrinsic process motivation is distinct from the classical interpretation of intrinsic motivation because the emphasis with the former is on immediate enjoyment or pleasure during the activity, rather than on the satisfaction that results from its achievement. The classic intrinsic motivation is better represented in this motivation taxonomy as self-concept-internal, to be explained in more detail in this paper.

Intrinsically motivated leaders find enjoyment and pleasure in the work they do (Barbuto, Fritz, \& Marx, 2002). The leaders' enjoyment of their work environment could inspire the followers to emulate the leaders' behavior and incorporate enjoyment with work (Avolio, Waldman, \& Einstein, 1988).

Hypothesis 1: Leaders' intrinsic process motivation will be positively related to charismatic and transformational leadership behaviors.

\section{Instrumental Motivation}

Instrumental rewards motivate individuals when they perceive their behavior will lead to certain extrinsic tangible outcomes, such as pay, promotions, bonuses, etc. (Kelman, 1958). This source of motivation integrates Etzioni's (1961) alienative and calculative involvement, Barnard's (1938) exchange theory, and Katz and Kahn's (1978) legal compliance and external rewards. Developmental theorists have described a similar motive as concrete operational (Piaget,
1972), instrumental (Kohlberg, 1976), imperial (Kegan, 1982), and opportunistic (Loevinger, 1976). Similar instrumental motives have been described by need theorists as a need for power (Murray, 1964; McClelland, 1961), a need for safety (Maslow, 1954), or late stages of existence needs (Alderfer, 1969).

Instrumental motivation is different from the classic extrinsic or external motivation (Deci, 1975; Katz \& Kahn, 1978; Staw, 1976) in that this motive derives from tangible external rewards, whereas the classic definition includes social rewards and interpersonal exchanges (in this typology, motivation that derives from these rewards is termed self-concept-external). Extrinsic motivation is further divided in this meta-theory into two categories of motives: tangible (instrumental) and social (self-conceptexternal). This motivation is characterized by optimizing self-interests, but with the recognition that every thing or want has its tangible price.

Instrumentally motivated leaders see the value in a reward system for employees (Barbuto, Fritz, \& Marx, 2002). Similarly, transactional leaders work within a system of reward/punishment for employees (Bass, 1990). We expect that leaders high in instrumental motivation will likely also be higher in transactional behaviors.

Hypothesis 2: Leaders' instrumental motivation will be positively related to transactional leadership behaviors.

\section{Self-Concept-External Motivation}

This source of motivation tends to be externally based when individuals are otherdirected and seek affirmation of traits, competencies, and values from external perceptions. The ideal self is adopted from the role expectations of reference groups, explaining why individuals high in self-concept-external motivation behave in ways that satisfy reference group members, first to gain acceptance, and after achieving that, to gain status.

This source of motivation is similar to Etzioni's (1961) social moral involvement, extrinsic interpersonal motivation described by Deci (1975) and Staw (1976), and Barnard's (1938) social inducements, conformity to group 
attitudes, and communion. This source of motivation also resembles social identity theory, in which the focus is on establishing and maintaining social reference and standing (Ashforth \& Mael, 1989). Developmental theorists have described a similar motivational stage as interpersonal (Kohlberg, 1976; Kegan, 1982), early formal operational (Piaget, 1972), and conformist (Loevinger, 1976).

Other researchers have described similar motivation as a need for affiliation (McClelland, 1961; Murray, 1964), need for love, affection, and belonging (Maslow, 1954), and as relatedness needs (Alderfer, 1969). Katz and Kahn (1978) describe employees seeking "membership and seniority in organizations," "approval from leaders," and "approval from groups" in terms similar to those used to describe self-concept-external motivation. Classic articulations of social rewards or social exchanges are consistent in concept and motivational explanation with self-conceptexternal motives.

Kuhnert and Lewis (1987) propose links between interpersonal motivations and highorder transactions, described here in terms similar to charismatic leadership. Barbuto and Scholl (1999) examined the relationship between work motivation and influence tactics used and found significant correlations between selfconcept-external motives and social tactics, such as ingratiating and personal appeals. Barbuto et al. (2000) examined motivation and transformational leadership and reported negative relationships between self-conceptexternal motivation and transformational leadership. We expect that self-concept-external motivation will share many characteristics with transactional leadership, but also will demonstrate some relationship with social transactions, such as those commonly described in the referent influences of charismatic leadership.

Hypothesis 3: Leaders' self-concept external motivation will be positively related to leaders' transactional and charismatic leadership behavior.

\section{Self-Concept-Internal Motivation}

Self-concept-based motivation will be internal when individuals are inner-directed. In this type of motivation, the individuals set internal standards for traits, competencies, and values that become the basis for their ideal selves (Leonard, Beauvais, \& Scholl, 1999). Persons are then motivated to engage in behaviors that reinforce these standards and later achieve higher levels of competency.

This source is similar to McClelland's (1961) need for achievement, Deci's (1975) internal motivation to overcome challenges, and Katz and Kahn's (1978) ideal of internalized motivation derived from role performance. Bellah et al. (1985) describe individualism in terms similar to those used to describe selfconcept internal motivation. Developmental theorists have described a similar stage using such terms as full formal operational (Piaget, 1972), social system (Kohlberg, 1976), institutional (Kegan, 1982), and conscientious (Loevinger, 1976). Similar motives are described as a need for achievement (McClelland, 1961; Murray, 1964), need for esteem (Maslow, 1954), motivating factors (Herzberg, 1968), and growth needs associated with developing one's potential (Alderfer, 1969).

Bandura (1986) describes self-evaluative mechanisms, self-regulation, and personal standards in terms similar to those used to describe self-concept-internal motivation. Katz and Kahn (1978) describe a motive similar to internalized motivation as "self-expression derived from role performance." This motive also has been described as "intrinsic motivation to overcome challenges" (Deci, 1975) and "intrinsic motivation to pursue personal achievement" (Staw, 1976).

A leader who is inspired by self-conceptinternal motivation is likely to value individual employees and the inherent strengths and contributions each makes. This leader's use of individualized consideration is likely to inspire followers to see the goals of the leader as well as goals for personal growth (Bass, 1985). Kuhnert and Lewis (1987) proposed relationships between Kegan's (1982) institutional stage of ego development, where the focus is on selfauthorship and self-determination, and transformational leadership. Barbuto and Scholl (1999) tested relationships between motivation and influence tactics and found some 
relationships between self-concept-internal motivation and inspirational appeals, consultation tactics, and rational persuasion. Of Yukl's (1998) ten influence tactics, these three seem to share the strongest behavioral similarities to transformational leadership. Barbuto et al. (2000) expected to find relationships between self-concept-internal and transformational leadership, but weren't able to demonstrate a relationship. We cautiously expect a relationship to exist between this motive and transformational leadership behaviors.

Hypothesis 4: Leaders' self-concept internal motivation will be positively related to leaders' charismatic and transformational leadership behaviors.

\section{Goal Internalization Motivation}

Behavior motivated by goal internalization occurs when individuals adopt attitudes and behaviors congruent with their personal value systems. Strong ideals and beliefs are paramount in this motivational source (Barbuto \& Scholl, 1998). Individuals motivated by goal internalization believe in the cause and have developed a strong sense of duty to work toward the goal of the collective.

This source of motivation is similar to Kelman's (1958) value system, Katz and Kahn's (1978) internalized values, Deci's internal valence for outcome (1975), and Etzioni's (1961) pure moral involvement. Each of these perspectives emphasizes a virtuous character and a desire not to compromise these virtues. Bellah et al. (1985) describe habits of the heart in terms similar to goal internalization. Developmental theorists describe a similar motivational stage as post-formal operational (Piaget, 1972), principled orientation (Kohlberg, 1976), interindividual (Kegan, 1982), and autonomous (Loevinger, 1976). Need theorists describe a similar motive as self-actualization (Maslow, 1954).

Goal internalization is different from the previous four sources of motivation because it is clearly marked by the absence of self-interest (Barbuto \& Scholl, 1998). Motivation from this source occurs when individuals believe in the cause. By contrast, individuals motivated by intrinsic process need to enjoy the work being performed. Those with high levels of instrumental motivation are driven to perform the work because of an incentive or contingent reward. Individuals with high levels of selfconcept-external motivation desire to enhance their reputation or image, while those with high levels of self-concept-internal motivation are stimulated by personal challenge and selfregulation. All of these reflect some degree of self-interest; on the other hand, those with high levels of goal internalization motivation are driven solely by a belief that the goals of the organization are both worthwhile and achievable.

Transformational leader behaviors are most typically seen in persons who trust and believe in the goal of the organization (Bass, 1985; Katz \& Kahn, 1978), naturally expanding to belief in the organization's cause. Barbuto and Scholl (1999) examined motivation's predictive value for influence tactics and found significant correlations between goal internalization motivation and both inspirational appeals and rational persuasion. From a transformational leadership perspective, it is expected that goal internalization will relate to inspirational leadership and charismatic behaviors. Barbuto et al. (2000) found significant relationships between leaders' goal internalization and use of transformational leadership behaviors. We expect similar findings in this study.

Hypothesis 5: Leaders' goal internalization motivation will be positively related to leaders' use of transformational leadership behaviors.

\section{Intrinsic and Extrinsic Motivation}

For the purpose of this study, we further divided the five sources of motivation into two categories: intrinsic/internal (Deci, 1975; Staw, 1976), comprised of intrinsic process, selfconcept-internal and goal internalization; and extrinsic/external (Deci, 1975; Staw, 1976), comprised of instrumental and self-conceptexternal. Intrinsic/internal motivation embodies the person and his or her emotions, encompassing fun, trust, and self-worth, all of which are derived from internal influences. These qualities are similar to those needed for transformational behaviors (Bass, 1985; Burns, 
1978; Bass, 1990). An extrinsic/external combined process really derives from the surroundings of the person (Barbuto \& Scholl, 1998). People influenced by an intrinsic/external process are motivated by prestige, rewards and status, perhaps more suitable to transactional and charismatic leadership (Hater \& Bass, 1988; Bass, 1990).
Hypothesis 6: Leaders' intrinsic/internal motivation will be positively related to charismatic and transformational leadership behaviors.

Hypothesis 7: Leaders' extrinsic/external motivation will be positively related to transactional leadership behaviors.

Figure 1 Summary of Hypotheses

\begin{tabular}{lcl} 
Motivation Sources & Direction of Influence & Leadership Behaviors \\
\hline Intrinsic Process & Positive & Charismatic Leadership \\
Motivation & Positive & Transformational Leadership \\
Instrumental Motivation & Positive & Transactional Leadership \\
Self-concept External & Positive & Transactional Leadership \\
Motivation & Positive & Charismatic Leadership \\
Self-Concept Internal & Positive & Charismatic Leadership \\
Motivation & Positive & Transformational Leadership \\
Goal Internalization & Positive & Transformational Leadership \\
Intrinsic/Internal & Positive & Charismatic Leadership \\
Motivation & Positive & Transformational Leadership \\
Extrinsic/External & Positive & Transactional Leadership \\
Motivation & Positive & Charismatic Leadership
\end{tabular}

\section{Methods}

\section{Sample}

Data from 186 leaders and their 759 raters were collected. Leaders were employed in a variety of industries, governmental agencies, and educational settings and in both rural and urban areas. All leaders had participated in an extensive twelve-month leadership-training program. Raters were not provided any formal training. Fifty-seven percent of the leaders were female, with an average age of 44 years. Leaders had an average tenure of 7.9 years with their companies and many had either a bachelor's $(61 \%)$ or master's $(15 \%)$ degree. Fifty-one percent of the raters were female, with an average age of 39 years. Raters had an average tenure of 5.8 years with their companies and were generally as well educated as their leaders $(57 \%$ had earned a bachelor's degree; $12 \%$ had earned a master's degree).

\section{Measures}

\section{Leaders' Behavior}

Leaders' laissez-faire, transactional (contingent reward, management by exception - passive and active), charismatic (idealized influence, behavior, and attributed), and transformational behaviors (inspirational motivation, individualized consideration, and intellectual stimulation) were measured using the Multi-factor Leadership Questionnaire (MLQ-short form) (Bass, 1985). These behaviors were assessed by both leaders (selfreport) and raters (rater form). Sample items and coefficient alphas for the items measured for the full range of leadership were (leader selfreport alpha appears first): laissez-faire ("Avoids getting involved when important issues arise," $\alpha$ $=.89 \& .76$ ); contingent reward ("Provides me with assistance in exchange for my efforts," $\alpha=$ .77 \& .77); management by exception - passive ("Fails to interfere until problems become serious," $\alpha=.73$ \& .72); management by exception - active ("Focuses attention on irregularities, mistakes, exceptions, and deviations from standards," $\alpha=.70 \& .71$ ), charismatic - behavior ("Talks about their most important values and beliefs," $\alpha=.78 \& .71$ ); attributed charisma ("Instills pride in me for being associated with him/her," $\alpha=.73 \& .79$ ); inspirational motivation ("Talks optimistically about the future," $\alpha=.72 \& .82$ ); individualized 
consideration (Spends time teaching and coaching," $\alpha=.69 \& .73$ ); and intellectual stimulation ("Seeks differing perspectives when solving problems," $\alpha=.76 \& .71$ ).

\section{Leaders' Motivation}

Leaders' sources of motivation were measured using the Motivation Sources Inventory (MSI) (Barbuto \& Scholl, 1998). The Inventory contains 30 items, six for each subscale, measured on a six point Likert-type scale. Motivation scores were obtained by calculating the mean response for each subscale. Sample items and coefficient alphas for the five sources of motivation were: intrinsic process ("I would prefer to do things that are fun" $\alpha=.71$ ); instrumental ("I like to be rewarded when I take on additional responsibilities" $\alpha=.78$ ); selfconcept external ("It is important to me that others appreciate the work I do" $\alpha=.85$ ); selfconcept internal ("Decisions I make reflect standards I've set for myself' $\alpha=.82$ ); and goal internalization ("I work hard for a company if I agree with its mission" $\alpha=.73$ ).

\section{Procedures}

Leaders completed and returned by mail to the researchers the Motivation Sources Inventory (MSI) and the Multi-factor Leadership Questionnaire (MLQ) four weeks prior to the workshop. Each leader also was provided the rater version of the Multi-factor Leadership Questionnaire (MLQ) to distribute to six employees. These instruments were coded and returned by mail directly to the researchers between six and three weeks prior to the respective workshops.

All leaders participating in this study were engaged in leadership development workshops being offered through university extension efforts. Leaders participating in the research project and workshop were provided with a twoday training session on both work motivation and full range leadership. The intact groups $(+/-$ 15 leaders) met for monthly follow-up sessions in cohort support teams to address issues and challenges they faced in the leadership development process.
Participation was optional and both leaders and raters were given the opportunity to withdraw from the study at any time, even after the workshop(s). To date, nobody has requested to be removed from the study. However, not all leaders had six raters return the forms, so full participation was not achieved. Leaders had been instructed to distribute the forms to those individuals most capable of assessing behaviors, but also were urged to select a wide variety of individuals, to avoid selecting favorable employees. An average of 4.1 usable rater forms per leader was returned to the researchers.

\section{Analysis}

Results of the study were analyzed using the computer program SPSS. Analysis of the Multi-factor Leadership Questionnaire of both raters' reports and leaders' self-reports began by calculating subscales of the full range leadership behaviors. Several subscales also were combined into broader categories of transformational leadership (inspirational motivation, individualized consideration, and intellectual stimulation), transactional leadership (contingent reward, management by exception active and management by exception - passive), charismatic leadership (idealized influence, attributed, and behavior) and laissez-faire leadership.

Analysis of the Motivation Sources Inventory included parceling the 30 motivation items into five individual subscales and two additional subscales. The two additional subscales combined individual motivations for a generic intrinsic (intrinsic process, self-conceptinternal, and goal internalization) and extrinsic (self-concept-external and instrumental) classification to allow for emergence of broad trends between internally driven and externally driven motivation patterns (Deci, 1975). Simple statistics and correlation analysis were used to interpret the data and test the hypothesized relationships among leaders' motivations and transformational, charismatic, transactional and laissez-faire leadership. 


\section{Results}

Several significant findings emerged from the analysis of the relationship between the Motivation Sources Inventory subscales (intrinsic, extrinsic, intrinsic process, instrumental, self-concept-external, selfconcept-internal, and goal internalization) and leaders' transformational behavior subscales (individualized consideration, inspirational and intellectual stimulation), charismatic leadership (idealized influence attributed and behavior), transactional leadership (contingent reward, management by exception - active and passive) and laissez-faire leadership. Simple statistics, reliability estimates, and Pearson (2-tailed) correlations were computed for the hypothesized variables (See Tables 1, 2 and 3).

Table 1

Motivation Subscales Inter-Correlations

\begin{tabular}{|c|c|c|c|c|c|c|c|c|c|}
\hline \multirow[b]{2}{*}{ Motivation } & \multirow[b]{2}{*}{$\mathrm{M}$} & \multicolumn{3}{|c|}{$\begin{array}{l}\text { Directional } \\
\text { Motivation }\end{array}$} & \multirow[b]{2}{*}{ Int.Proc } & \multirow[b]{2}{*}{ Instrum } & \multicolumn{3}{|c|}{$\begin{array}{l}\text { Meta-Theory of } \\
\text { Motivation Sources }\end{array}$} \\
\hline & & $\mathrm{SD}$ & Intrinsic & Extrinsic & & & $\mathrm{SCE}$ & $\mathrm{SCI}$ & GI \\
\hline Intrinsic/Internal & 67.30 & 9.64 & .91 & & & & & & \\
\hline Extrinsic/External & 33.16 & 10.38 & $.43 * *$ & .87 & & & & & \\
\hline Intrinsic Process & 15.96 & 3.18 & $.20 * *$ & .04 & .71 & & & & \\
\hline Instrumental & 16.71 & 5.68 & $.37^{* *}$ & $.89 * *$ & .03 & .78 & & & \\
\hline Self-Concept External & 16.46 & 6.05 & $.41^{* *}$ & $.90 * *$ & .04 & $.60 * *$ & .85 & & \\
\hline Self-Concept Internal & 29.47 & 3.98 & $.67 * *$ & .08 & $.18^{* *}$ & .01 & $.13 *$ & .82 & \\
\hline Goal Internalization & 23.23 & 5.16 & $.81^{* *}$ & $.23 * *$ & $.13^{*}$ & $.19 * *$ & $.23 * *$ & $.40^{* *}$ & .73 \\
\hline
\end{tabular}

Note: $\quad \mathrm{N}=186,{ }^{*} \mathrm{p}<.01$ (two-tailed), ${ }^{*} \mathrm{p}<.05$ (two-tailed). Int.Proc $=$ Intrinsic Process), Insrum $=$ Instrumental, SCE $=$ Self-Concept External, $\mathrm{SCI}=$ Self-Concept Internal, GI=Goal Internalization. Coefficient alphas $(\alpha)$ on diagonals.

Table 2

Motivation Subscales and Leaders' Self-Reported Full Range Leadership

\begin{tabular}{|c|c|c|c|c|c|c|c|c|c|c|}
\hline \multirow[b]{2}{*}{ Leader MLQ } & \multirow[b]{2}{*}{$\mathbf{M}$} & \multirow[b]{2}{*}{ SD } & \multicolumn{3}{|c|}{$\begin{array}{l}\text { Motivational } \\
\text { Direction }\end{array}$} & & & \multicolumn{3}{|c|}{$\begin{array}{l}\text { Meta-Theory of } \\
\text { Motivation Sources }\end{array}$} \\
\hline & & & $\alpha \quad I_{1}$ & Intrinsic $\mathrm{I}$ & Extrinsic & Int.Pro & Instrum & SCE & SCI & GI \\
\hline Transformational 2.91 & 0.41 & .88 & $.18^{* *}$ & $\quad-.08$ & & $.29 * *$ & -.11 & -.05 & $.32 * *$ & .10 \\
\hline Inspir. Motivation & 2.90 & 0.61 & .72 & $.17^{* *}$ & .05 & $.29 * *$ & -.01 & .09 & $.27^{* *}$ & .07 \\
\hline Indiv. Consideration & 3.14 & 0.48 & .69 & .07 & $-.16^{* *}$ & $.26^{* *}$ & $-.16^{* *}$ & $-.13 *$ & $.23 * *$ & .03 \\
\hline Intellect. Stimulation & 2.83 & 0.51 & .76 & $.23^{* *}$ & -.00 & $.10^{*}$ & .01 & -.01 & $.27 * *$ & $.15^{* *}$ \\
\hline Charisma & 2.82 & 0.49 & .76 & $.15^{*}$ & $-.17 * *$ & $.24 * *$ & $-.19 * *$ & -.12 & $.26^{* *}$ & .10 \\
\hline Attributed Charisma & 2.80 & 0.53 & .73 & $.16^{* *}$ & -.09 & $.18^{* *}$ & -.12 & -.05 & $.27 * *$ & .09 \\
\hline Charismatic Behavior & 2.84 & 0.62 & .78 & .11 & $-.20 * *$ & $.24 * *$ & $-.20 * *$ & $-.17 * *$ & $.18 * *$ & .11 \\
\hline Transactional & 1.84 & 033 & .68 & .01 & $.18 * *$ & .08 & $.14^{*}$ & $.17 * *$ & -.06 & .01 \\
\hline Contingent Rewards & 2.84 & 0.53 & .77 & .12 & -.02 & $.31^{* *}$ & -.01 & .04 & $-.28 * *$ & .06 \\
\hline MBE & 1.31 & 0.48 & .71 & -.05 & $.19 * *$ & -.07 & $.15^{*}$ & $.19 * *$ & $-.18 * *$ & -.02 \\
\hline MBE Passive & 1.22 & 0.59 & .73 & -.07 & $.16^{* *}$ & -.03 & $.13^{*}$ & $.16^{* *}$ & $-.23 * *$ & .00 \\
\hline MBE Active & 1.39 & 0.66 & .70 & -.05 & $.12 *$ & -.08 & .10 & .11 & -.05 & -.05 \\
\hline Laissez-Faire & 0.78 & 0.46 & .89 & .01 & $.16^{* *}$ & -.07 & $.13^{*}$ & $.16^{* *}$ & -.08 & .01 \\
\hline
\end{tabular}

Note: $\mathrm{N}=731,{ }^{* *} \mathrm{p}<.01$ (two-tailed), ${ }^{*} \mathrm{p}<.05$ (two-tailed). MBE=Management-by-Exception, MBE Passive= Management-byException Passive, MBE Active=Management-by-Exception Active, Int.Proc. $=$ Intrinsic Process, Instrum $=$ Instrumental, SCE $=$ SelfConcept External, SCI = Self-Concept Internal, GI = Goal Internalization 
Table 3

Motivation Subscales and Raters' Reported Full Range Leadership

\begin{tabular}{|c|c|c|c|c|c|c|c|c|c|c|}
\hline \multirow[b]{2}{*}{ Rater MLQ } & \multirow[b]{2}{*}{$\mathrm{M}$} & \multirow[b]{2}{*}{ SD } & \multicolumn{4}{|c|}{$\begin{array}{l}\text { Motivational } \\
\text { Direction }\end{array}$} & \multirow[b]{2}{*}{ Instrum } & \multirow[b]{2}{*}{ SCE } & \multicolumn{2}{|c|}{$\begin{array}{l}\text { Meta-Theory of } \\
\text { Motivation }\end{array}$} \\
\hline & & & $\alpha$ & Intrinsic & Extrinsic & Int.Proc & & & $\mathrm{SCI}$ & GI \\
\hline Transformational & 2.95 & 0.60 & .85 & .06 & -.12 & .16 & -.09 & -.12 & .04 & -.04 \\
\hline Inspir. Motivation & 3.07 & 0.71 & .82 & .10 & .03 & $.18^{*}$ & .07 & -.02 & .04 & -.01 \\
\hline Indiv. Consideration & 2.85 & 0.78 & .73 & -.02 & $-.19^{*}$ & .06 & -.16 & $-.19^{*}$ & .03 & -.06 \\
\hline Intellect. Stimulation & 2.79 & 0.72 & .71 & .13 & -.08 & .14 & -.04 & -.10 & .15 & .01 \\
\hline Charisma & 2.99 & 0.65 & .77 & .13 & -.06 & $.16^{*}$ & -.04 & -.07 & .12 & .03 \\
\hline Attributed Charisma & 3.07 & .073 & .79 & .12 & -.01 & $.16^{*}$ & .02 & -.03 & .15 & -.00 \\
\hline Charismatic Behavior & 2.88 & 0.71 & .71 & .10 & -.11 & .11 & -.08 & -.11 & .07 & .05 \\
\hline Transactional & 1.88 & 0.47 & .74 & $.23^{*}$ & $.29 * *$ & $.30 * *$ & $.25^{* *}$ & $.26^{* *}$ & -.03 & .13 \\
\hline Contingent Rewards & 2.91 & 0.75 & .77 & .14 & .03 & .15 & .03 & .03 & .14 & .03 \\
\hline MBE & 1.37 & 0.67 & .74 & $.18^{*}$ & $.27^{* *}$ & $.25^{* *}$ & $.26^{* *}$ & $.23^{* *}$ & -.08 & .14 \\
\hline MBE $P$ assive & 1.08 & 0.80 & .72 & $.17^{*}$ & .19 & $.16^{*}$ & .12 & .13 & -.02 & .14 \\
\hline MBE Active & 1.62 & 0.93 & .71 & .10 & $.27^{* *}$ & $.23^{* *}$ & $.24 * *$ & $.23 * *$ & -.13 & .07 \\
\hline Laissez-Faire & 0.69 & 0.71 & .76 & .10 & $.18^{*}$ & .09 & .15 & $.17^{*}$ & -.09 & .13 \\
\hline
\end{tabular}

Note: $\mathrm{N}=594,{ }^{* *} \mathrm{p}<.01$ (two-tailed), ${ }^{*} \mathrm{p}<.05$ (two-tailed). MBE= Management-by-Exception, MBE Passive $=$ Management-byException Passive, MBE Active=Management-by-Exception Active, Int.Proc = Intrinsic Process, Instrum = Instrumental, SCE =Self Concept External, SCI =Self Concept Internal, GI = Goal Internalization

\section{Motivation as an Antecedent of Transformational Leadership}

Leaders' intrinsic process motivation significantly correlated with their self-reported transformational behaviors $(\mathrm{r}=.29 ; \mathrm{p}<.01)$, inspirational motivation $(\mathrm{r}=.29 ; \mathrm{p}<.01)$, individualized consideration $(\mathrm{r}=.26 ; \mathrm{p}<.01)$, and intellectual stimulation $(\mathrm{r}=.10 ; \mathrm{p}<.05)$ (H1). Leaders' intrinsic process motivation also demonstrated several significant relationships with raters' perceptions of leader behaviors. Leaders' intrinsic process motivation also proved to be significantly related to inspirational motivation $(\mathrm{r}=.18 ; \mathrm{p}<.05)$. Taken together, these results demonstrate several significant relationships between leaders' intrinsic process motivation and their use of transformational leadership ( $\mathrm{H} 1)$.

Leaders' instrumental motivation shared a negative relationship with their self-reported individualized consideration $(\mathrm{r}=-.16 ; \mathrm{p}<.05)$.

Leaders' self-concept external motivation was negatively related to their self-reported individualized consideration $(\mathrm{r}=-.13 ; \mathrm{p}<.05$ and to raters' perceptions of leaders' individualized consideration $(r=-.19 ; \mathrm{p}<.01)$. There was no significant relationship between self-concept-external motivation and charismatic leadership behaviors $(\mathrm{H} 3)$.

Leaders' self-concept-internal motivation significantly correlated with their self-reported transformational behaviors $(\mathrm{r}=.32, \mathrm{p}<.01)$, inspirational motivation $(\mathrm{r}=.27, \mathrm{p}<.01)$, individualized consideration $(\mathrm{r}=.23, \mathrm{p}<.01)$, and intellectual stimulation $(\mathrm{r}=.27, \mathrm{p}<.01)$ (H4). However, there were no significant relationships between self-concept-internal motivation and raters' perceptions of transformational leadership.

Goal internalization significantly correlated with leaders' self-reported intellectual stimulation ( $\mathrm{r}=.15, \mathrm{p}<.01)(\mathrm{H} 5)$. Leaders' combined intrinsic motivation significantly correlated with their self-reported transformational behaviors $(\mathrm{r}=.18, \mathrm{p}<.01)$, inspirational motivation $(\mathrm{r}=.17, \mathrm{p}<.01)$, and intellectual stimulation $(r=.23, p<.01)(\mathrm{H} 6)$. Leader's combined extrinsic motivation was negatively related to their self-reported individualized consideration $(\mathrm{r}=-.16 ; \mathrm{p}<.01)$ and rater-reported individualized consideration $(r=-.19 ; p<.01)$. 


\section{Motivation as an Antecedent to Charismatic Leadership}

Relationships also were found between leaders' intrinsic process motivation and their self-reports of each of the charismatic subscales: charisma $(\mathrm{r}=.24 ; \mathrm{p}<.01)$, attributed charisma $(\mathrm{r}$ $=.18 ; \mathrm{p}<.01)$, and charismatic behavior $(\mathrm{r}=$ $.24 ; \mathrm{p}<.01)(\mathrm{H} 1)$. Intrinsic process motivation also significantly correlated with attributed charisma $(\mathrm{r}=.16 ; \mathrm{p}<.05)$.

Leaders' instrumental motivation negatively related to two of the three selfreported charismatic subscales: charisma $(\mathrm{r}=$ $.19 ; \mathrm{p}<.01)$ and charismatic behavior $(\mathrm{r}=-.20$; $\mathrm{p}<.01)$.

Leaders' self-concept-external motivation negatively related to their self-reported charismatic behavior $(\mathrm{r}=-.17, \mathrm{p}<.01)(\mathrm{H} 3)$. Leaders' self-concept-internal motivation significantly related to three of their selfreported charismatic subscales: charisma $(r=$ $.26, \mathrm{p}<.01)$, attributed charisma $(\mathrm{r}=.27, \mathrm{p}<$ $.01)$, and charismatic behavior $(\mathrm{r}=.18, \mathrm{p}<.01)$ (H4).

As expected, goal internalization shared no significant variance with any of the charismatic leadership subscales.

Leaders' combined intrinsic group significantly correlated with two of the leaders' self-reported charismatic behaviors: charismatic behavior $(\mathrm{r}=.15, \mathrm{p}<.05)$ and attributed charisma $(r=.16, p<.01)(H 6)$. Leaders' extrinsic combined group was negatively related to their self-reported charisma $(\mathrm{r}=-.17 ; \mathrm{p}<.01)$ and charismatic behavior $(\mathrm{r}=-.20 ; \mathrm{p}<.01)$ (H7).

\section{Motivation as an Antecedent to Transactional Leadership}

Leaders' intrinsic process motivation positively related to their self-reported use of contingent rewards $(r=.31 ; p<.01)$ and to rater-reported transactional leadership $(\mathrm{r}=.30 ; \mathrm{p}$ $<.01)$, management by exception $(\mathrm{r}=.25 ; \mathrm{p}<$ $.01)$, passive management by exception $(\mathrm{r}=.16$; $\mathrm{p}<.05$ ), and active management by exception ( $\mathrm{r}$ $=.23 ; \mathrm{p}<.01)$.

Leaders' instrumental motivation significantly correlated with leaders' selfreported transactional behaviors $(\mathrm{r}=.14, \mathrm{p}<$ $.01)$, management by exception $(\mathrm{r}=.15, \mathrm{p}<$
$.01)$, passive management by exception $(\mathrm{r}=.13$, $\mathrm{p}<.01)$, and laissez-faire leadership $(\mathrm{r}=.13, \mathrm{p}<$ .01). Leaders' instrumental motivation also demonstrated significant relationships with raters' perceptions of transactional leadership ( $\mathrm{r}$ $=.25, \mathrm{p}<.01)$, management by exception $(\mathrm{r}=$ $.26, \mathrm{p}<.01$ ), and active management by exception $(\mathrm{r}=.24, \mathrm{p}<.01)$.

Leaders' self-concept-external motivation showed significant relationships with three of their self-reported transactional behaviors: transactional leadership $(\mathrm{r}=.17, \mathrm{p}<.01)$, management by exception $(\mathrm{r}=.19, \mathrm{p}<.01)$, passive management by exception $(\mathrm{r}=.16, \mathrm{p}<$ $.01)$, and laissez-faire leadership $(\mathrm{r}=.16, \mathrm{p}<$ $.01)$. Leaders' self-concept-external motivation also demonstrated significant relationships with raters' perceptions of transactional leader behaviors: transactional leadership $(\mathrm{r}=.26, \mathrm{p}<$ $.01)$, management by exception $(\mathrm{r}=.23, \mathrm{p}<$ $.01)$, and active management by exception $(\mathrm{r}=$ $.23, \mathrm{p}<.01)$.

Leaders' self-concept-internal motivation showed negative relationships with their selfreported use of contingent rewards $(\mathrm{r}=-.28 ; \mathrm{p}<$ $.01)$, management by exception $(\mathrm{r}=-.18 ; \mathrm{p}<$ $.01)$, and passive management by exception $(\mathrm{r}=$ $-.23 ; \mathrm{p}<.01)$. Goal internalization shared no significant variance with any of the transactional leadership subscales.

The leaders' combined intrinsic group significantly related to rater perceptions of transactional leadership $(\mathrm{r}=.23 ; \mathrm{p}<.01)$, management by exception $(r=.18 ; \mathrm{p}<.05)$, and passive management by exception $(\mathrm{r}=.17 ; \mathrm{p}<$ $.05)$.

The leaders' combined extrinsic group significantly correlated with leaders' selfreported transactional behaviors: transactional $r$ $=.18, \mathrm{p}<.01)$, management by exception $(\mathrm{r}=$ $.19, \mathrm{p}<.01$ ), passive management by exception $(\mathrm{r}=.16, \mathrm{p}<.01)$, active management by exception $(\mathrm{r}=.12, \mathrm{p}<.05)$, and laissez-faire leadership $(\mathrm{r}=.16, \mathrm{p}<.01)(\mathrm{H} 7)$. Leaders' combined extrinsic motivation was significantly related with transactional leadership $(\mathrm{r}=.29, \mathrm{p}<$ $.01)$, management by exception $(r=.27, p<$ $.01)$, active management by exception $(\mathrm{r}=.27, \mathrm{p}$ $<.01)$, and laissez-faire leadership $(\mathrm{r}=.18, \mathrm{p}<$ $.05)$. 


\section{Discussion}

The leaders' self-reports of transformational leadership had a higher correlation to the five sources of motivation than did the raters' reports of full range leadership. Leaders' work motivation demonstrated some correlations with leadership behaviors, but the relationships generally accounted for less than $5 \%$ variance. Other general trends noted were that self-concept-internal motivation related to transformational behaviors, while self-conceptexternal motivation related more closely to transactional behaviors.

This study distinguished charismatic behaviors from transformational ones as criterion variables, but, in most cases, those behaviors that were significantly correlated with transformational subscales also were significantly correlated with charismatic subscales. This result may be explained by the nature of the measure itself, which was not designed to distinguish between inspirational and charismatic influences. It may also reflect the operational definitions used for charismatic leadership (idealized influence) in the original development of the subscale (Bass, 1985). Bass (1990) reported that no empirical distinction had yet been between inspirational and charismatic leadership subscales, which remain true in light of this study.

Intrinsic process motivation correlated with transformational behaviors, indicating that leaders motivated by fun at work are more likely to self-report an ideology consistent with transformational and charismatic leadership. Intrinsic process motivation was related to rater perceptions of transactional leadership, indicating that those high in intrinsic process tend to view selves as more transformational, while those around them tend to view them as more transactional.

Instrumental motivation correlated with transactional behaviors, contingent rewards, management by exception, management by exception - active and laissez-faire leadership. This correlation may have been expected since prior work reported a similar result (Barbuto, Fritz \& Marx, 2000). However, this same result indicates that instrumental motivation shares little variance with transformational leadership behaviors, consistent with propositions developed in the ego constructive development literature (Kuhnert \& Lewis, 1987). Selfconcept-external motivation correlated with some charismatic behavior and transactional behavior, but didn't share significant variance with transformational behaviors in the study. This result may have been expected, given the social rewards and interpersonal or referent nature of charismatic leadership behaviors and the focus on interpersonal feedback attributed to self-concept external motivation. This result also moderately supports the premise that charismatic and transformational leadership may be distinct constructs and necessitate different motives from leaders (See Barbuto, 1997). Since individuals with high self-conceptexternal motivation appear to exhibit more charismatic behaviors, some support for Kegan's (1982) lens perspective is found, by which leaders may naturally assume the extent to which followers require self-concept external motives to be satisfied will be similar to their own.

Overall, motivation has provided some evidence for promise as an antecedent to full range leadership. Most relationships proved to move in the expected directions and the effect sizes compared favorably to previous antecedent research conducted in the area of transformational leadership (Atwater \& Yammarino, 1993; Avolio, 1994; Barbuto et al., 2000; Bass, 1985; Howard \& Bray, 1988). Still, the relationships leave the field open to many more questions of how to identify the best antecedents of transformational leadership. Because motivation explains a small amount of variance in full range leadership, continued search for other salient variables is necessary.

\section{Implications for Practice}

The results of this study have some selection and leadership development implications. If specific leadership styles (i.e., transformational) are sought in organizations, some motivation profiling may prove conducive to selecting individuals who have a greater likelihood of displaying these behaviors. However, we caution practitioners to be leery of 
overestimating the relevance of leaders' sources of motivation to their leadership style, as the results of this study showed a relatively small effect. The source of motivation may provide one of many pieces of information to consider when making recruiting and leadership development decisions. Other important factors, such as academic preparation, job fit, experiences, and work philosophies - which were not tested in this study - may play a large role in determining behaviors and likely will have a role in recruiting leaders.

The result of this study is consistent with Kegan's (1982) constructive developmental view of human motivation and its role in leadership formation and development. The lens perspective offers a guideline for understanding limitations of leaders, essentially that leaders see the world through their own paradigm or "lens" and assume others share a similar lens. Kuhnert and Lewis (1987) advocate a similar perspective in their conceptual work linking Kegan's (1982) levels of ego development with transactional and transformational behaviors. However, stronger effect sizes would be necessary to generalize Kegan's work to this study.

\section{Opportunities for Future Research}

The results of this study provide several opportunities for future research. The relationships between motivation and full range leadership were consistent, but also produced generally small effects. Studying human motivation in combination with other salient variables may be necessary to glean the best antecedents of full range leadership. It appears that motivation explains some variance in the construct, but greater explanation is possible. Greater attention is needed in testing other dispositional variables and their relations to transformational leadership. Alternative measurement strategies for capturing charismatic leadership may be developed to discover charismatic effects distinct from transformational ones.

More rigorous procedures will also improve research in this area. The common data collection method for antecedent research of transformational leadership has been to use leaders and designated raters, chosen by leaders. This snowball effect produces a non-random sample, which likely impacts response bias and confounds results. More random rater selection will address this concern, as will the inclusion of social desirability in the research design. By controlling for and assessing response bias, antecedent research will have more functional credibility. Additionally, in instances where research participation is part of a leadership development initiative, the impact of such training on the data collection processes and responses needs to be planned and assessed.

Other antecedents of full range leadership behavior need to be tested to better understand the construct. To date, early childhood experiences, locus of control, early career challenges, personality, and motivation all have been explored as dispositional antecedents of full range leadership with relatively small effect sizes. To explain greater variance, future research may test other salient variables, such as political skills, mental boundaries or flexibility, self-presentation, and other attitudinal constructs that may provide valuable exploration into the field of leadership antecedents. Additionally, other leadership frameworks need to be examined to ascertain the dispositional role that work motivation plays as an antecedent to leadership. Motivation links with other leadership perspectives, such as leader-member exchange quality, servant leadership, authentic leadership, ideological leadership, political leadership, and others, may provide a rich test and contribution to the antecedent field. We believe that greater attention to the antecedents of leadership will prove valuable to field.

\section{References}

Alderfer, C. P. (1969). An empirical test of a new theory of human needs. Organizational Behavior and Human Performance, 4, 142175.

Argyris, C. (1954). Human relations in a bank. Harvard Business Review, 32, 63-72.

Ashforth, B., \& Mael, F. (1989). Social identity theory and the organization. Academy of Management Review, 14, 20-39. 
Atwater, L. E., \& Yammarino, F. J. (1993). Personal attributes as predictors of superiors' and subordinates' perceptions of military academy leadership. Human Relations, 46, 645-668.

Avolio, B. J. (1994). The "natural": Some antecedents to transformational leadership. International Journal of Public Administration, 17, 1559-1581.

Avolio, B. J., Waldman, D.A., \& Einstein, W.O. (1988). Transformational leadership in a management game simulation. Group \& Organization Studies, 13, 59-79.

Bandura, A. (1986). Social foundations of thought and action: $A$ social cognitive theory. Englewood Cliffs, NJ: Prentice Hall.

Barbuto, J. E. (1997). Taking the charisma out of transformational leadership. Journal of Social Behavior and Personality, 12, 689697.

Barbuto, J. E. (2000). Influence triggers: A framework for understanding follower compliance. Leadership Quarterly, 11, 365387.

Barbuto, J. E., Fritz, S. M., \& Marx, D. (2000). A field study of two measures of work motivation for predicting leader's transformational behaviors. Psychological Reports, 86, 295-300.

Barbuto, J. E., Fritz, S. M., \& Marx, D. (2002). A field study examining two measures of work motivation for predicting leaders' influence tactics used. Journal of Social Psychology, 142(5), 601-616.

Barbuto, J. E., \& Scholl, R. W. (1998). Motivation Sources Inventory: Development and validation of new scales to measure an integrative taxonomy of motivation. Psychological Reports, 82, 1011-1022.

Barbuto, J. E., \& Scholl, R. W. (1999). Leaders' sources of motivation and perceptions of followers' motivation as predictors of leaders' influence tactics used. Psychological Reports, 84, 1087-1098.

Barnard, C. (1938). The functions of the executive. Cambridge, MA: Harvard Press.

Bass, B. M. (1985). Leadership and performance beyond expectations. New York: Free Press.

Bass, B. M. (1990). Bass and Stodgill's handbook of leadership. New York: Free Press.
Bass, B. M. \& Avolio, B.J. (1990). Developing transformational leadership: 1992 and beyond. Journal of European Industrial Training, 14, 21-27.

Bellah, R. N., Madsen, R., Sullivan, W. M., Swidler, A., \& Tipton, S. M. (1985). Habits of the heart:

Individualism and commitment in American life. Berkeley, CA: University of California Press.

Berrien, F. K. (1961). Homeostasis theory of groups - implications for leadership. In $\mathrm{L}$. Petrullo \& B. Bass (Eds.), Leadership and interpersonal behavior. New York: Holt, Rinehart \& Winston.

Blanchard, H., \& Johnson, S. (1985). The oneminute manager. Berkeley, CA: Berkeley Publishing Co.

Bradford, L. P., \& Lippitt, R. (1945). Building a democratic work group. Personnel, 22(3), 142-148.

Burns, J. M. (1978). Leadership. New York: Harper \& Row.

Deci, E. L. (1975). Intrinsic motivation. New York: Plenum Press.

Deluga, R. J. (1988). Relationship of transformational and transactional leadership with employee

influencing strategies. Group and Organizational Studies, 13, 456-467.

Etzioni, A. (1961). A comparative analysis of complex organizations. Glencoe, IL: Free Press.

Hater, J. J., \& Bass, B. M. (1988). Superiors' evaluations and subordinates' perceptions of transformational and transactional leadership. Journal of Applied Psychology, 73(4), 695-702.

Herzberg, F. W. (1968). One more time, how do you motivate employees? Harvard Business Review, 46(1), 53-62.

House, R. J., Spangler, W. D., \& Woycke, J. (1991). Personality and charisma in the U.S. presidency: A psychological theory of leadership effectiveness. Administrative Science Quarterly, 36, 364-396.

Howard, A., \& Bray, D. W. (1988). Managerial lives in transition: Advancing age and changing times. New York: Guilford Press. 
Howell, J. M., \& Avolio, B. J. (1993). Transformational leadership, transactional leadership, locus of control, and support for innovation: Key predictor of consolidatedbusiness-unit performance. Journal of Applied Psychology, 78, 891-902.

Howell, J., \& Frost, P. J. (1989). A laboratory study of charismatic leadership. Organizational Behavior and Human Decision Processes, 43, 243-269.

Hunt, J. G. (1999). Transformational/charismatic leadership's transformation of the field: An historical essay. Leadership Quarterly, 10(2), 129-144.

Katz, D., \& Kahn, R. L. (1978). The social psychology of organizations. New York: Wiley.

Katz, D., Macoby, N., Gurin, G., \& Floor, L. (1951). Productivity, supervision, and morale among railroad workers. Ann Arbor: University of Michigan, Institute for Social Research.

Kegan, R. (1982). The evolving self. Cambridge, MA: Harvard University Press.

Kelman, H. C. (1958). Compliance, identification, and internalization: Three processes of attitude change. Journal of Conflict Resolution, 2, 51-56.

Kohlberg, L. (1976). Collected papers on moral development and moral education. Cambridge, MA: Center for Moral Education.

Kuhnert, K., \& Lewis, P. (1987). Transactional \& transformational leadership: A constructive developmental analysis. Academy of Management Review. 12(4),_648-657.

Leonard, N. H., Beauvais, L L., \& Scholl, R. W. (1999). Work motivation: The incorporation of self concept-based processes. Human Relations, 52, 969-998.

Lewin, K., Lippitt, R., \& White, R. K. (1939). Patterns of aggressive behavior in experimentally created social climates. Journal of Social Psychology, 10, 271-301.
Lowe, K. B., Kroeck, K. G., \& Sivasubramaniam, N. (1996). Effectiveness correlates of transformational leadership: A meta-analytic review of the MLQ literature. Leadership Quarterly, 7, 385-425.

Loevinger, J. (1976). Ego development. San Francisco: Jossey-Bass, Inc.

Maslow, A. (1954). Motivation and personality. New York: Harper \& Row.

McClelland, D. C. (1961). The achieving society. Princeton, NJ: Van Nostrand.

McClelland, D. C. (1985). Human motivation. Glenview, IL: Scott, Foresman.

Murnigham, J. K., \& Leung, T. K. (1976). The effects of leadership involvement and the importance of the task on subordinates' performance. Organizational Behavior and Human Performance, 17, 299-310.

Murray, E. J. (1964). Motivation and emotion. Englewood Cliffs, NJ: Prentice-Hall.

Piaget, J. (1972). Intellectual evolution from adolescence to adulthood. Human Development, 15, 1-12.

Podsakoff, P. M., MacKenzie, S. B., Morrman, R. H., \& Fetter, R. (1990). Transformational leader behaviors and their effects on followers' trust in leader, satisfaction, and organizational citizenship behaviors. Leadership Quarterly, 1, 107-142.

Seltzer, J., \& Bass, B. M. (1990). Transformational leadership: Beyond initiation and consideration. Journal of Management, 16(4), 693-703.

Staw, B. M. (1976). Intrinsic and extrinsic motivation. Morristown, NJ: Silver Burdett.

Weber, M. (1947). The theory of social and economic organizations. New York: Free Press.

Yammarino, F. J., \& Bass, B. M. (1990). Transformational leadership and multiple levels of analysis.

Human Relations, 43, 975-995.

Yukl, G. A. (1998). Leadership in organizations. New York: Prentice Hall. 